\title{
US electric utility deregulation: the genie is out of the bottle
}

\author{
by Edward L Flippen
}

Electric utility deregulation, which started out as a movement to improve reliability and reduce prices, was almost ended with the California fiasco, the bankruptcy of Enron, and the worst blackout in US history. Indeed, the actions taken by many states following these and other events demonstrated a resolve to halt deregulation and, in several instances, turn the clock back to the "good old days" of "cost-plus" regulation.

We all remember those good old days. Utilities built whatever type and size facilities they wanted; ratepayers paid for bad decisions; and rate cases were filed every couple of years to cover continually increasing costs. Yep, they were the good old days. They were good for utility managers (few, if any, lost their jobs for bad investment decisions); good for regulators (great power); good for consultants (who prepared and filed "canned" testimony around the country); and good for lawyers (who always knew their clients would get rate increases - they just didn't know how much).

Yes sir, the good old days were certainly good, perhaps not for the customers, but what the heck, they could handle a multi-million dollar rate increase every year or so if it did not cause "rate shock," the regulators' euphemism for how much rates could increase before customers and politicians started to complain. Simply put, in the good old days customers got all the risk, and utility management, regulators, consultants, and lawyers got all the money. It is no wonder that the good old days look so good to some.

In some states the good old days remain, but in others there is no going back. The genie is out of the bottle. Management has changed, thousands of employees have been let go, "build" decisions are based on sound capital budgeting analyses, and utilities are joining regional markets to improve reliability and reduce cost.

How anyone could argue that the good old days are better for consumers than participation in competitive markets, improved efficiency and enhanced reliability, is beyond me (as are lots of things). What is not beyond me is what I have observed in 30 years of representing consumer groups, industrial customers, utilities, and power plant developers. I've seen the good old days when it didn't make a "hill of beans" what things cost the utility. It didn't matter what accounting and legal fees were, or how much was paid to consultants. I've also observed first hand what deregulation has done in telecommunications, natural gas and electricity. Without question, it's not pretty. Competition never is. Companies struggle, customers are taken advantage of by fly-by-night marketers, alternatives can be confusing, and customers have to make choices.

These are the by-products of competition. But so are recruiting and maintaining the best and brightest managers, reducing costs, improving efficiencies, quantum leaps in technology, and perhaps most important, conservation and a better environment. With competition will come alternative forms of energy and "time of use" pricing (ie, you pay for what it actually costs the utility). With competition, the US, which produces nearly 18 per cent of the world's energy while consuming 24 per cent of it will become part of the solution - not part of the problem.

We got where we are because of the good old days. We can get out in the "good new days." They won't all be pretty days. They won't be neat and tidy and they will scare the pants off politicians, but there's no turning back. Too many legislators and regulators have made the decision to substitute competition for regulation in their state. True, it's been a scary road to date. California's deregulation plan looked stupid (and much of it was). Enron demonstrated how major changes in an industry structure create opportunities for the wheeler-dealer. And the August 14, 2003 northeast blackout - the worst in US history pointed out how vulnerable our safety, health and economy are to disruptions in electric service.

All of this causes us to question the need to change from the good old days of regulation to the new days of deregulation. Worse yet, the cases of California, Enron, and the blackout do not end our questions; they have only begun. Many other events will cause us to question whether deregulation of electricity, a service as fundamental to our economic well-being as air and water, is in the public interest.

Regardless of these inevitable concerns, the genie is out of the bottle. The US is on the road to improve electric efficiency and reliability, lower prices, and create a better environment. More than anything else, politics will determine how long and rough that road is. Certain federal and state politicians will continue to resist deregulation until the end, and that's fine with me. I'm one of the lawyers that do well in such squabbles. I'm also one that hopes the good old days don't last too long. I have four 
grandchildren between two and six years of age; I'm hoping they'll see a healthier environment and a more reliable electric system in their adult years. Indeed, I'm betting they will. The good old boys are smart, but I haven't seen one yet who can put the genie back in the bottle. They aren't that smart. (c)

\section{IALS Lectures}

Monday, 29 November

JAMES MICHAEL

Former Special Adviser to the House of Lords Select Committee on the Freedom of Information Bill; IALS Associate Senior Research Fellow

* One month to go: will the Freedom of Information Act change anything about British government and business?

Wednesday, 8 December

\section{DR MAHMOOD BAGHERI}

Lecturer in law, Brunel University; IALS Associate Research Fellow

Private international law and the rights/utilitarianism dichotomy

Monday, 31 January 2005

\section{DR CENTO VELJANOVSKI}

Managing Partner, Case associates; IALS Associate Research Fellow

* Law and economies: where are we four decades on?

\section{International and European Environmental and Energy Law Lecture Series}

Monday, 17 January 2005, 5-6.30pm

Organised in Association with the British Institute of International and Comparative Law and Imperial College, University of London
Edward L Flippen

Partner, McGuire Woods LLP, Richmond, Virginia

\section{KAREN MORROW}

Senior lecturer in law, Brunel University

The rights question: the Human Rights Act and the environment

\section{Issues in Family Law}

Tuesday, 18 January 2005

\section{PROFESSOR GWYNN DAVIS}

University of Bristol

Contact disputes, the courts and legal aid: have we reached the end of the road?

\section{Issues in Cultural Property}

Wednesday, 2 February 2005

\section{PROFESSOR PATRICK BOYLAN}

Professor Emeritus, Department of Arts Policy and Management, City University

Legal protection for cultural property during armed conflicts: past, present and future

* denotes lecture eligible for one Law Society CPD hour and one General Council of the Bar CPD hour.

Drinks and light refreshments will follow. Admission free all welcome. All lectures will be held from $6-7 \mathrm{pm}$ at the Institute of Advanced Legal Studies, 17 Russell Square, London WC1, unless otherwise stated. For further information please contact Belinda Crothers (tel: 020 7862 5841; email: Belinda.Crothers@sas.ac.uk).

\section{SALS Lectures}

\section{Joint SALS-Law Commission lecture}

Thursday, 2 December

\section{MR JUSTICE TOULSON}

Chairman, Law Commission

The Law Commission's report on partial defences to murder

\section{Joint SALS-British Insurance}

\section{Law Association lecture}

Thursday, 9 December

\section{PHILIP RAWLINGS}

Norton Rose Senior Lecturer in Commercial Law, UCL

\section{JOHN LOWRY}

Senior Lecturer, UCL

Framing the insurer's post contractual duty of good faith

Admission free - all welcome. Booking is requested for all events, which will take place at the Institute of Advanced Legal Studies, 17 Russell Square, London WC1 at 6pm unless otherwise stated. Please contact the SALS office (tel: 0207862 5865; email: sals@sas.ac.uk) for further information. 